\title{
Profil Penguasaan Konsep Struktur Atom pada Siswa Kelas X MIPA SMA Negeri 4 Palangka Raya Tahun Ajaran 2018/2019
}

\author{
Yulita Tasya*, I Made Sadiana, Nopriawan Berkat Asi \\ Program Studi Pendidikan Kimia, Jurusan Pendidikan MIPA, FKIP, Universitas \\ Palangka Raya, Indonesia \\ E-mail :yulitatasya50@gmail.com
}

Diterima: 10 Februari 2020; Disetujui: 24 Februari 2020; Diterbitkan: 12 Maret 2020

\begin{abstract}
ABSTRAK
Struktur atom merupakan salah satu materi pelajaran kimia yang diajarkan di SMA/MA. Materi ini dipelajari dikelas X SMA tentang perkembangan teori atom, partikel dasar penyusun atom, konfigurasi elektron, serta bilangan kuantum. Konsep ini merupakan konsep dasar ilmu kimia untuk memahami ikatan kimia. Penelitian ini bertujuan untuk mendeskripsikan profil penguasaan konsep Struktur Atom pada siswa kelas X SMA. Penelitian ini merupakan jenis penelitian deskriptif yang dilaksanakan di SMA Negeri 4 Palangka Raya dengan subjek penelitian adalah 30 siswa kelas X MIPA-1. Data yang digunakan pada penelitian ini berupa dokumen RPP guru kimia yang bersangkutan, data penguasaan konsep siswa yang didapat melalui tes uraian, dan data hasil wawancara siswa. Hasil penelitian menunjukkan 1) rata-rata sebesar $62,16 \%$ berada pada kategori sedang. 2) Siswa dapat menjelaskan perkembangan teori atom untuk menunjukkan kelebihan dan kekurangan masing-masing teori atom dengan rata-rata penguasaan konsep sebesar 68,75\% dengan kategori sedang. 3) Siswa dapat menentukan partikel dasar (proton, elektron, dan neutron) suatu atom berdasarkan nomor atom dan nomor massa dengan rata-rata penguasaan konsep sebesar $61,47 \%$ dengan kategori sedang. 4) Siswa dapat mengklasifikasi unsur ke dalam isotop, isobar, dan isoton dengan rata-rata penguasaan konsep sebesar $88,88 \%$ dengan kategori tinggi. 5) Siswa dapat menentukan bilangan kuantum pada elektron terluar dari suatu unsur atau ion dengan rata-rata penguasaan konsep sebesar $21,04 \%$ dengan kategori rendah.
\end{abstract}

Kata Kunci: konsep, penguasaan, profil, struktur atom

\section{PENDAHULUAN}

Pendidikan di Indonesia telah diatur dalam Undang-Undang Nomor 20 Tahun 2003 tentang Sistem Pendidikan Nasional (SISDIKNAS). Menurut UU.RI.No.20 Tahun 2003 sistem pendidikan nasional mempunyai visi terwujudnya sistem pendidikan sebagai pranata sosial yang kuat dan berwibawa untuk memberdayakan semua warga negara indonesia berkembang menjadi manusia yang berkualitas sehingga mampu dan proaktif menjawab tatangan zaman yang selalu berubah (Arifin, 2011). 
Kimia merupakan salah satu bidang ilmu dalam Ilmu Pengetahuan Alam, kimia terbentuk dari fakta, konsep, prinsip, teori, dan hukum, yang termasuk pengetahuan deklaratif dan cara bagaimana pengetahuan itu terbentuk yang dikelompokkan dalam pengetahuan prosedural. Dimensi pengetahuan meliputi pengetahuan faktual, konseptual, prosedural dan metakognitif. Pengetahuan faktual bersifat konkret dan sejajar dengan bepikir tingkat rendah. Pengetahuan prosedural sejajar dengan berpikir tingkat tinggi. Pengetahuan metakognitif bersifat abstrak yang merupakan strategi kognitif (Asi, 2018). Pengetahuan itu terbangun dari konsep-konsep, pengetahuan tertentu yang memiliki bentuk organisasi konsep atau struktur tertentu dengan sifatnya yang berbeda (Arifin, 2007). Siswa perlu memiliki kemampuan bernalar ilmiah dalam memahami sains termasuk kimia. Pola-pola penalaran ilmiah memungkinkan siswa menganalisis fakta atau informasi secara logis dan sistematis (Anggraeni, 2018). Struktur atom adalah salah satu materi kimia yang diajarkan di SMA/MA. Materi ini dipelajari dikelas X MIA semester 1, dengan konsep yang harus dipahami oleh siswa yaitu perkembangan teori atom, partikel dasar penyusun atom, konfigurasi elektron, serta bilangan kuantum. Konsep ini merupakan konsep dasar yang harus dipahami siswa, jika konsep ini tidak dipahami dengan baik maka siswa akan sulit memahami konsep-konsep selanjutnya seperti sistem periodik unsur dan ikatan kimia tetapi masih banyak siswa yang belum mampu menguasai konsep struktur atom dengan benar.

Oleh karena itu diperlukan adanya analisis terhadap penguasaan konsep siswa agar mengetahui penyebab kesalahan siswa dalam menyelesaikan soal-soal struktur atom sehingga kesalahan tersebut tidak terjadi secara berlanjut dan dapat ditentukan secara tepat bentuk remediasi untuk permasalahan ini. Sebagaimana penjelasan tersebut, peneliti hendak mengetahui sejauh mana penguasaan konsep siswa ditinjau dari proses pembelajaran di sekolah melalui pemberian tes tanpa diberikan suatu perlakuan terhadap subjek penelitian. Hasil analisis penguasaan konsep siswa ini nantinya akan dikaitkan dengan RPP guru, materi pembelajaran yang diajarkan di kelas, dan dikonfirmasi kembali dengan guru. Hasil belajar siswa akan menggambarkan apakah tujuan pembelajaran yang diharapkan oleh guru tercapai atau belum tercapai serta hasil tes tersebut akan menggambarkan bagaimana penguasaan konsep siswa pada materi struktur atom.

Berdasarkan pemaparan diatas maka peneliti tertarik melakukan penelitian tentang bagaimana profil penguasaan konsep Struktur Atom pada siswa kelas X MIPA-1 SMA Negeri 4 Palangka Raya Tahun Ajaran 2018/2019.

Penelitian ini bertujuan untuk mendeskripsikan profil penguasaan konsep Struktur Atom pada siswa kelas X MIPA-1 SMA Negeri 4 Palangka Raya Tahun Ajaran 2018/2019.

\section{METODOLOGI PENELITIAN}

Penelitian ini dilaksanakan di SMA Negeri 4 Palangka Raya yang beralamat di jalan Sisingamangaraja III no.3, kelurahan Menteng, kecamatan Jekan Raya, Kota Palangka Raya. Subjek penelitian ini adalah 30 siswa kelas X MIPA-1 SMA Negeri 4 Palangka Raya Tahun Ajaran 2018/2019 dimana siswa tersebut telah menerima pembelajaran tentang Struktur Atom. Pengambilan data penelitian ini dilaksanakan pada tanggal 26 September 2018 dengan alokasi waktu yang diberikan untuk mengerjakan soal sebanyak 3 jam pelajaran. 
Data yang dikumpulkan dalam penelitian ini berupa: dokumen RPP, Data penguasaan konsep berupa tes, dan wawancara. Dokumen RPP didapat dari guru dengan ijin dari sekolah yang bersangkutan. Data penguasaan konsep siswa dijaring dengan memberikan tes uraian kepada siswa. Tes diberikan kepada siswa kelas X MIPA-1 SMA Negeri 4 Palangka Raya dengan tujuan untuk mengetahui tingkat kemampuan atau sejauh mana penguasaan konsep siswa terhadap materi Struktur Atom. Soal dikerjakan secara individu tanpa membuka buku. Saat mengerjakan soal siswa diawasi oleh guru dan peneliti sehingga dapat diasumsikan bahwa siswa mengerjakan berdasarkan kemampuan siswa itu sendiri. Hasil jawaban siswa menggambarkan tingkat penguasaan konsep siswa yang dijadikan dasar dalam penyusunan hasil wawancara. Wawancara dilaksanakan atas ijin guru mata pelajaran yang bersangkutan.

Teknik analisis data dalam penelitian ini berupa analisis RPP, analisis data penguasaan konsep, dan hasil wawancara. Analisis data rencana pelaksanaan pembelajaran (RPP) dilakukan dengan langkah-langkah berikut:

1. RPP dianalisis kelengkapan komponennya, dengan komponen RPP yang dianalisis sebagai berikut:

Tabel 1. Komponen RPP

\begin{tabular}{|c|c|c|c|}
\hline No & Aspek yang Diamati & Ada & $\begin{array}{c}\text { Tidak } \\
\text { Ada }\end{array}$ \\
\hline & Identitas Sekolah & & \\
\hline & A. Satuan Pendidikan & & \\
\hline & B. Kelas & & \\
\hline \multirow[t]{6}{*}{1} & C. Semester & & \\
\hline & D. Mata Pelajaran & & \\
\hline & E. Materi Pokok & & \\
\hline & F. Alokasi Waktu & & \\
\hline & Kompetensi Inti & & \\
\hline & $\mathrm{KI}-1$ & & \\
\hline \multirow[t]{3}{*}{2} & $\mathrm{KI}-2$ & & \\
\hline & $\mathrm{KI}-3$ & & \\
\hline & $\mathrm{KI}-4$ & & \\
\hline 3 & Kompetensi Dasar & & \\
\hline 4 & Indikator & & \\
\hline 5 & Tujuan Pembelajaran & & \\
\hline 6 & Materi Pembelajaran & & \\
\hline 7 & Metode Pembelajaran & & \\
\hline 8 & Media Pembelajaran & & \\
\hline 9 & Sumber Belajar & & \\
\hline \multirow[t]{7}{*}{10} & Rencana Kegiatan Pembelajaraan & & \\
\hline & Kegiatan pendahuluan/awal & & \\
\hline & 1) Mengkondisikan peserta didik & & \\
\hline & 2) Mengkaitkan materi sebelumnya & & \\
\hline & A dengan materi yang akan & & \\
\hline & dipelajari & & \\
\hline & 3) Menyampaikan tujuan & & \\
\hline
\end{tabular}




\begin{tabular}{|c|c|c|c|}
\hline No & Aspek yang Diamati & Ada & $\begin{array}{c}\text { Tidak } \\
\text { Ada } \\
\end{array}$ \\
\hline & Kegiatan inti & & \\
\hline & 1) Mengamati & & \\
\hline & 2) Menanya & & \\
\hline & B 3) Mengumpulkan data & & \\
\hline & 4) Mengasosiasikan & & \\
\hline & 5) Mengkomunikasikan & & \\
\hline & Kegiatan Penutup & & \\
\hline & 1) Meninjau kembali & & \\
\hline & 2) Mengevaluasi & & \\
\hline & 3) Tindak lanjut & & \\
\hline 11 & Penilaian & & \\
\hline & A Jenis/teknik penilaian & & \\
\hline & B Bentuk instrumen dan instrument & & \\
\hline
\end{tabular}

2. Peneliti menganalisis RPP yang berkaitan dengan KI (kompetensi inti), KD (kompetensi dasar), indikator pencapaian kompetensi, tujuan pembelajaran, dan materi pembelajaran. berikut:

Analisis data penguasaan konsep dilakukan dengan langkah-langkah

1. Jawaban siswa diberi skor sebagai data untuk mengetahui skor siswa sesuai dengan kriteria penskoran. Soal yang digunakan dalam penelitian ini berbentuk uraian yang berjumlah 16 butir soal. Hasil skor yang diperoleh digunakan untuk mendeskripsikan penguasaan konsep siswa tentang struktur atom. Penilaian sesuai dengan kriteria penguasaan konsep siswa dalam konsep struktur atom yang disajikan pada lampiran 7 .

2. Total perolehan skor seluruh siswa digunakan untuk menentukan penguasaan konsep siswa secara keseluruhan menggunakan rumus:

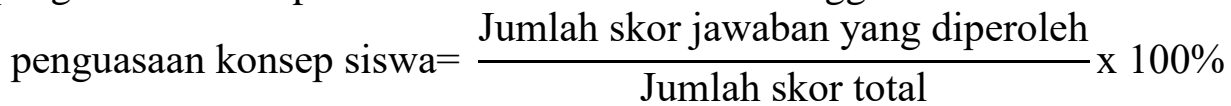

3. Penguasaan konsep siswa dikategorisasi sesuai kriteria penguasaan konsep yang disarankan oleh Arikunto.

Tabel 2. Kriteria Penguasaan Konsep (Arikunto, 2007)

\begin{tabular}{cc}
\hline Nilai $(\%)$ & Kategori \\
\hline $0-45$ & Rendah \\
$46-65$ & Sedang \\
$66-85$ & Tinggi \\
$86-100$ & Sangat Tinggi \\
\hline
\end{tabular}

4. Penguasaan konsep siswa dideskripsikan berdasarkan jawaban siswa pada masing-masing kategori tingkat penguasaan konsep siswa.

5. Penguasaan konsep pada materi struktur atom merupakan rata-rata dari penguasaan konsep yang diukur dari pencapaian indikatornya, ditentukan dengan rumus:

$$
\text { penguasaan konsep }=\frac{\sum \text { pencapaian indikator }}{\sum \text { indikator }}
$$


Hasil wawancara siswa dianalisis dengan teknik triangulasi. Teknik triangulasi yaitu teknik pemeriksaan keabsahan data yang memanfaatkan sesuatu yang lain dalam membandingkan hasil wawancara terhadap objek penelitian (Moloeng, 2004). Hasil wawancara dianalisis dengan cara sebagai berikut:

1. Hasil wawancara siswa dikonfirmasi dengan hasil jawaban siswa.

2. Hasil wawancara siswa dikonfirmasi dengan dokumen RPP guru mata pelajaran kimia yang mengajar.

3. Hasil wawancara siswa dikonfirmasi kembali dengan guru mata pelajaran kimia yang bersangkutan.

\section{HASIL PENELITIAN DAN PEMBAHASAN}

Penelitian ini dilaksanakan setelah materi pelajaran telah diberikan oleh guru mata pelajaran yang bersangkutan. Hasil jawaban siswa kemudian diolah sebagai data penguasaan konsep siswa. Butir soal pada tes uraian mewakili konsep-konsep pada materi struktur atom, dimana setiap butir soal memiliki kriteria penskoran. Total skor yang didapat siswa dikonversikan dalam bentuk persentase penguasaan dan kemudian diklasifikasikan kedalam tingkat penguasaan siswa.

Tabel 3. Capaian Penguasaan Konsep Siswa pada Materi Struktur Atom

\begin{tabular}{|c|c|c|c|c|}
\hline Indikator & Sub Indikator & $\begin{array}{l}\text { Butir } \\
\text { Soal }\end{array}$ & $\begin{array}{c}\text { Penguasaan } \\
\text { Konsep } \\
(\%)\end{array}$ & Kategori \\
\hline \multirow{4}{*}{$\begin{array}{l}\text { Menjelaskan } \\
\text { perkembangan } \\
\text { teori atom untuk } \\
\text { menunjukkan } \\
\text { kelebihan dan } \\
\text { kekurangan } \\
\text { masing-masing } \\
\text { teori atom. }\end{array}$} & $\begin{array}{l}\text { Menjelaskan kelebihan } \\
\text { dan kekurangan dari } \\
\text { teori atom Dalton. }\end{array}$ & $1 . \mathrm{a}$ & 88,33 & $\begin{array}{l}\text { Sangat } \\
\text { Tinggi }\end{array}$ \\
\hline & $\begin{array}{l}\text { Menjelaskan kelebihan } \\
\text { dan kekurangan dari } \\
\text { teori atom Thomson. }\end{array}$ & 1.b & 96,66 & $\begin{array}{l}\text { Sangat } \\
\text { Tinggi }\end{array}$ \\
\hline & $\begin{array}{l}\text { Menjelaskan kelebihan } \\
\text { dan kekurangan dari } \\
\text { teori atom Rutherford. }\end{array}$ & 1.c & 43,33 & Rendah \\
\hline & $\begin{array}{l}\text { Menjelaskan kelebihan } \\
\text { dan kekurangan dari } \\
\text { teori atom Bohr. }\end{array}$ & 1.d & 46,66 & Sedang \\
\hline \multirow{5}{*}{$\begin{array}{l}\text { Menentukan } \\
\text { partikel dasar } \\
\text { (proton, } \\
\text { elektron, dan } \\
\text { neutron) suatu } \\
\text { atom } \\
\text { berdasarkan } \\
\text { nomor atom dan } \\
\text { nomor massa. }\end{array}$} & $\begin{array}{l}\text { Menentukan proton, } \\
\text { elektron, dan neutron } \\
\text { suatu unsur netral. }\end{array}$ & 2.a & 75,55 & Tinggi \\
\hline & $\begin{array}{l}\text { Menentukan proton, } \\
\text { elektron, dan neutron } \\
\text { suatu ion positif. }\end{array}$ & 2.b & 75,55 & Tinggi \\
\hline & $\begin{array}{l}\text { Menentukan proton, } \\
\text { elektron, dan neutron } \\
\text { suatu ion negatif. }\end{array}$ & 2.c & 74,44 & Tinggi \\
\hline & $\begin{array}{l}\text { Menentukan nomor } \\
\text { atom suatu unsur. }\end{array}$ & 3.a & 53,33 & Sedang \\
\hline & $\begin{array}{l}\text { Menentukan nomor } \\
\text { massa suatu unsur. }\end{array}$ & 3.b & 50,00 & Sedang \\
\hline
\end{tabular}




\begin{tabular}{|c|c|c|c|c|}
\hline Indikator & Sub Indikator & $\begin{array}{c}\text { Butir } \\
\text { Soal }\end{array}$ & $\begin{array}{c}\text { Penguasaan } \\
\text { Konsep } \\
(\%)\end{array}$ & Kategori \\
\hline & $\begin{array}{l}\text { Menuliskan simbol atom } \\
\text { yang dilengkapi dengan } \\
\text { nomor atom dan nomor } \\
\text { massa. }\end{array}$ & 3.c & 40,00 & Rendah \\
\hline \multirow{3}{*}{$\begin{array}{l}\text { Mengklasifikasi } \\
\text { unsur ke dalam } \\
\text { isotop, isobar, } \\
\text { dan isoton. }\end{array}$} & $\begin{array}{l}\text { Mengklasifikasi } \\
\text { beberapa unsur ke } \\
\text { dalam isotop. }\end{array}$ & 4.a & 90,00 & $\begin{array}{l}\text { Sangat } \\
\text { Tinggi }\end{array}$ \\
\hline & $\begin{array}{l}\text { Mengklasifikasi } \\
\text { beberapa unsur ke } \\
\text { dalam isobar. }\end{array}$ & 4.b & 90,00 & $\begin{array}{l}\text { Sangat } \\
\text { Tinggi }\end{array}$ \\
\hline & $\begin{array}{l}\text { Mengklasifikasi } \\
\text { beberapa unsur ke } \\
\text { dalam isoton. }\end{array}$ & 4.c & 86,66 & $\begin{array}{l}\text { Sangat } \\
\text { Tinggi }\end{array}$ \\
\hline \multirow{3}{*}{$\begin{array}{l}\text { Menentukan } \\
\text { bilangan } \\
\text { kuantum pada } \\
\text { elektron terluar } \\
\text { dari suatu unsur } \\
\text { atau ion. }\end{array}$} & $\begin{array}{l}\text { Menentukan bilangan } \\
\text { kuantum (n, } l, \mathrm{~m} \text {, dan } \mathrm{s}) \\
\text { pada elektron terluar } \\
\text { dari suatu unsur netral. }\end{array}$ & 5.a & 52,50 & Sedang \\
\hline & $\begin{array}{l}\text { Menentukan bilangan } \\
\text { kuantum (n, } l, \mathrm{~m} \text {, dan } \mathrm{s}) \\
\text { pada elektron terluar } \\
\text { dari suatu ion positif. }\end{array}$ & $5 . \mathrm{b}$ & 4,16 & Rendah \\
\hline & $\begin{array}{l}\text { Menentukan bilangan } \\
\text { kuantum (n, } l, \mathrm{~m} \text {, dan } \mathrm{s}) \\
\text { pada elektron terluar } \\
\text { dari suatu ion negatif. }\end{array}$ & 5.c & 27,50 & Rendah \\
\hline \multicolumn{3}{|c|}{ Rata-rata penguasaan konsep } & 62,16 & Sedang \\
\hline
\end{tabular}

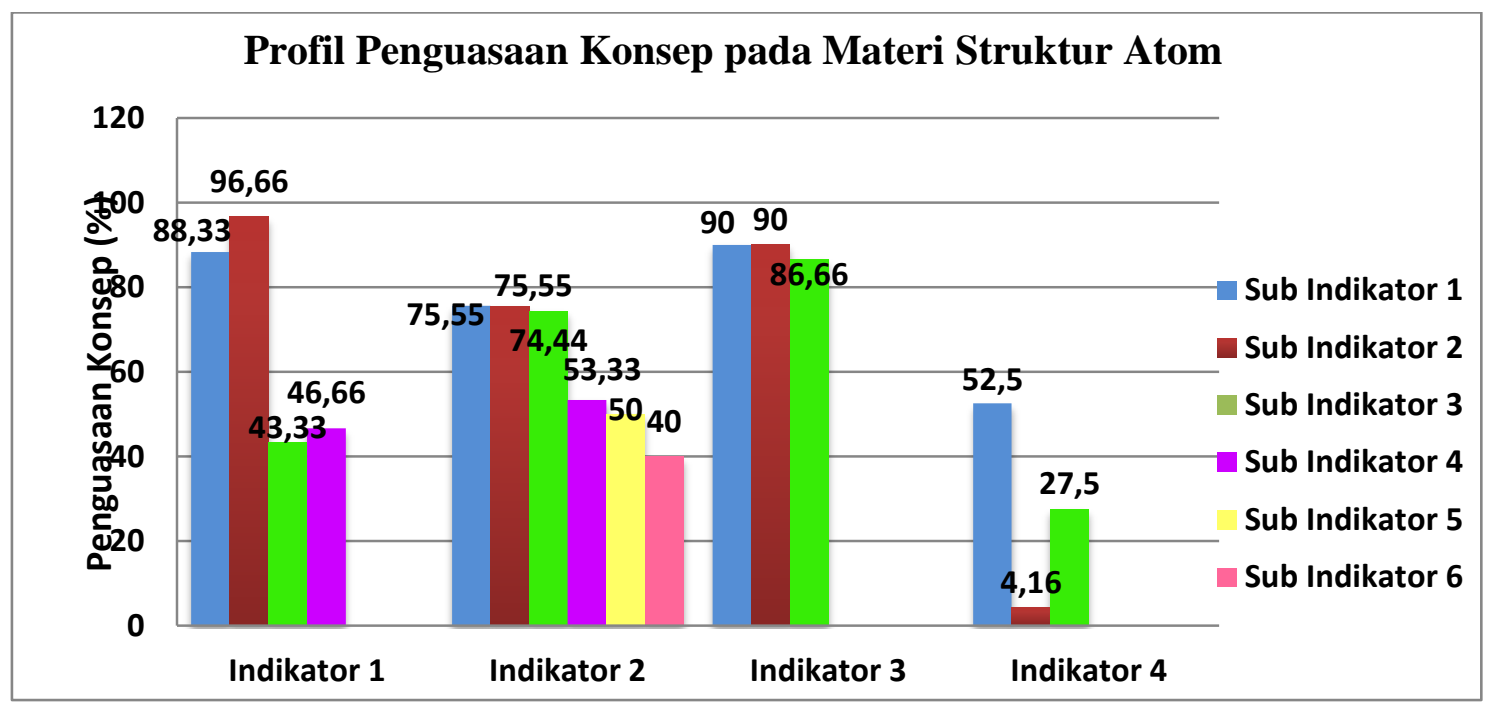

Gambar 1. Grafik Profil Capaian Penguasaan Konsep Siswa pada masingmasing Sub Indikator 
Tabel 7 dan grafik 1 merupakan hasil olahan data perolehan skor siswa pada materi struktur atom, menunjukkan bahwa penguasaan konsep siswa masih rendah dengan rata-rata persentase sebesar $62,16 \%$, nilai tersebut masih dibawah nilai KKM yang ditentukan sekolah tersebut yaitu 75 . Rata-rata penguasaan konsep siswa pada indikator 1 sebesar $68,75 \%$, penguasaan konsep siswa pada indikator 2 sebesar $61,47 \%$, penguasaan konsep siswa pada indikator 3 sebesar $88,88 \%$, dan penguasaan konsep siswa pada indikator 4 sebesar 28,05\%. Sehingga berdasarkan KKM, penguasaan konsep siswa pada materi ini masih rendah. Grafik 2 berikut menunjukkan capaian penguasaan konsep siswa secara individu.

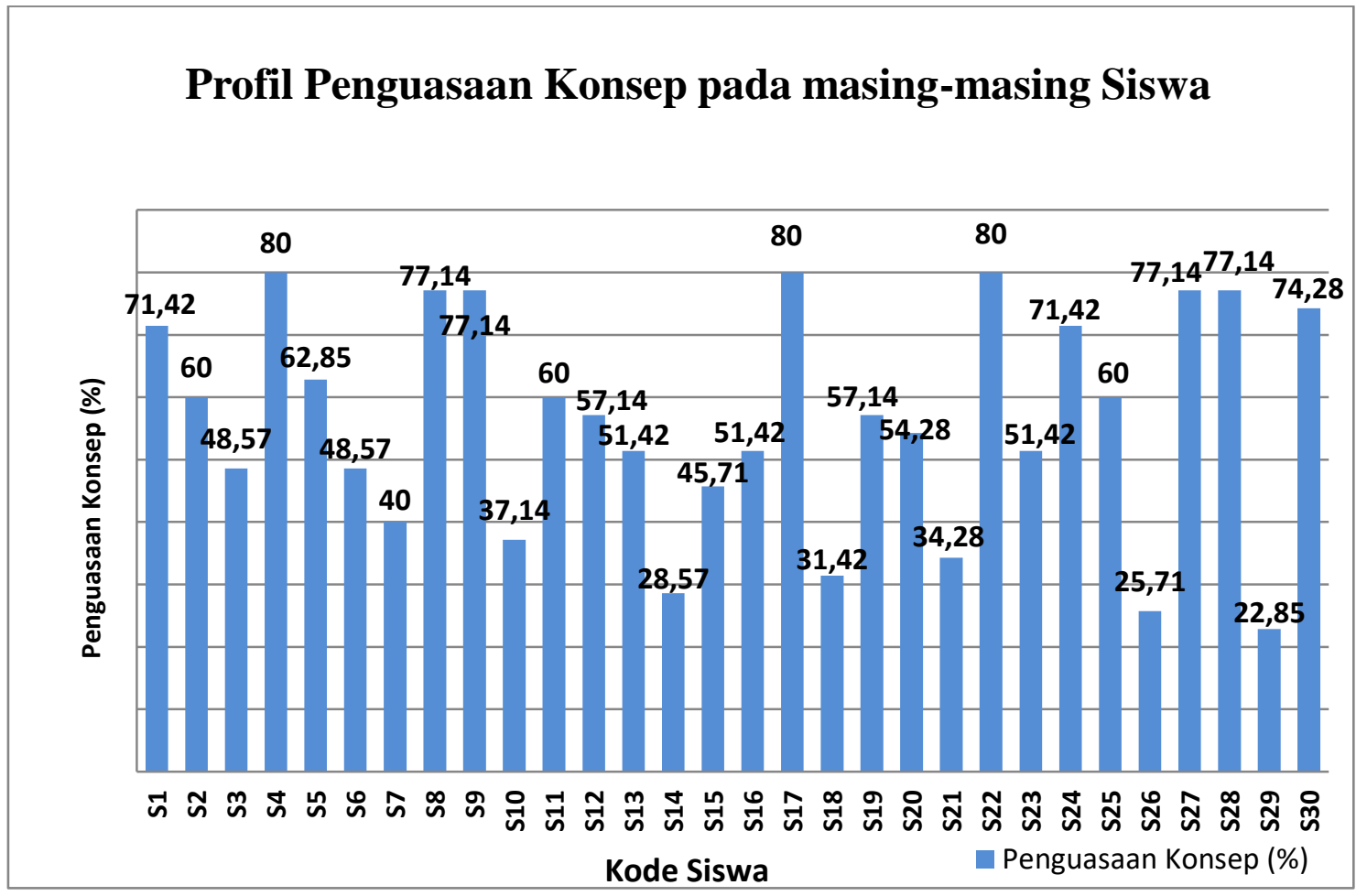

Gambar 2. Grafik 2 Profil Capaian Penguasaan Konsep pada masing-masing Siswa

Hasil penguasaan konsep struktur atom masing-masing siswa pada grafik 2 menunjukkan ada 7 siswa yang memperoleh nilai tuntas di atas KKM, dan 23 siswa memperoleh nilai di bawah KKM. Sebagaimana dipaparkan pada grafik, terdapat 4 kategori tingkat penguasaan konsep siswa yaitu sebesar 33\% (10 siswa) berada pada kategori tinggi, sebesar 44\% (13 siswa) berada pada kategori sedang, dan sebesar 26,66\% (7 siswa) berada pada kategori rendah.

Rencana Pelaksanaan Pembelajaran (RPP) yang diamati dan di analisis adalah RPP yang dibuat oleh guru berdasarkan kurikulum 2013. Untuk menganalisis RPP

tersebut digunakan pedoman seperti pada tabel 8 berikut.

Tabel 9. Pedoman Analisis RPP

\begin{tabular}{cccc}
\hline No & Aspek yang Diamati & Ada & $\begin{array}{c}\text { Tidak } \\
\text { Ada }\end{array}$ \\
\hline 1 & Identitas Sekolah & $\sqrt{ }$ &
\end{tabular}




\begin{tabular}{|c|c|c|c|}
\hline No & Aspek yang Diamati & Ada & $\begin{array}{c}\text { Tidak } \\
\text { Ada }\end{array}$ \\
\hline \multirow{11}{*}{2} & A. Satuan Pendidikan & $\sqrt{ }$ & \\
\hline & B. Kelas & $\sqrt{ }$ & \\
\hline & C. Semester & $\sqrt{ }$ & \\
\hline & D. Mata Pelajaran & $\sqrt{ }$ & \\
\hline & E. Materi Pokok & $\sqrt{ }$ & \\
\hline & F. Alokasi Waktu & $\sqrt{ }$ & \\
\hline & Kompetensi Inti & $\sqrt{ }$ & \\
\hline & $\mathrm{KI}-1$ & $\sqrt{ }$ & \\
\hline & $\mathrm{KI}-2$ & $\sqrt{ }$ & \\
\hline & KI-3 & $\sqrt{ }$ & \\
\hline & $\mathrm{KI}-4$ & $\sqrt{ }$ & \\
\hline 3 & Kompetensi Dasar & $\sqrt{ }$ & \\
\hline 4 & Indikator & $\sqrt{ }$ & \\
\hline 5 & Tujuan Pembelajaran & $\sqrt{ }$ & \\
\hline 6 & Materi Pembelajaran & $\sqrt{ }$ & \\
\hline 7 & Metode Pembelajaran & $\sqrt{ }$ & \\
\hline 8 & Media Pembelajaran & $\sqrt{ }$ & \\
\hline 9 & Sumber Belajar & $\sqrt{ }$ & \\
\hline \multirow[t]{15}{*}{10} & Rencana Kegiatan Pembelajaraan & $\sqrt{ }$ & \\
\hline & Kegiatan pendahuluan/awal & $\sqrt{ }$ & \\
\hline & 4) Mengkondisikan peserta didik & $\sqrt{ }$ & \\
\hline & $\begin{array}{l}\text { 5) Mengkaitkan materi sebelumnya } \\
\text { dengan materi yang akan } \\
\text { dipelajari }\end{array}$ & $\sqrt{ }$ & \\
\hline & $\begin{array}{l}\text { 6) Menyampaikan tujuan } \\
\text { pembelajaran }\end{array}$ & $\sqrt{ }$ & \\
\hline & Kegiatan inti & $\sqrt{ }$ & \\
\hline & 6) Mengamati & $\sqrt{ }$ & \\
\hline & B 7) Menanya & $\sqrt{ }$ & \\
\hline & B 8) Mengumpulkan data & $\sqrt{ }$ & \\
\hline & 9) Mengasosiasikan & $\sqrt{ }$ & \\
\hline & 10) Mengkomunikasikan & $\sqrt{ }$ & \\
\hline & Kegiatan Penutup & $\sqrt{ }$ & \\
\hline & 4) Meninjau kembali & $\sqrt{ }$ & \\
\hline & C 5) Mengevaluasi & $\sqrt{ }$ & \\
\hline & 6) Tindak lanjut & $\sqrt{ }$ & \\
\hline \multirow[t]{3}{*}{11} & Penilaian & $\sqrt{ }$ & \\
\hline & A Jenis/teknik penilaian & $\sqrt{ }$ & \\
\hline & B Bentuk instrumen dan instrumen & $\sqrt{ }$ & \\
\hline
\end{tabular}

Berdasarkan data analisis kompetensi isi RPP guru, data hasil analisis tersebut secara umum isinya telah sesuai seperti pada aspek yang diamati. Adapun 
pada penelitian ini, lebih spesifik pada aspek keterkaitan antara KI, KD, indikator pencapaian kompetensi, tujuan pembelajaran, materi pembelajaran, serta model pembelajaran yang digunakan. Berikut diuraikan keterkaitan antara komponenkomponen tersebut.

KD yang digunakan dalam penelitian ini yaitu 3.2 Memahami model atom Dalton, Thomson, Rutherfod, Bohr, dan mekanika gelombang dan 4.2 Menggunakan model atom untuk menjelaskan fenomena alam atau hasil percobaan. KD 3.2 telah memenuhi KI-3 pengetahuan, dimana pengetahuan yang akan diperoleh siswa berdasarkan $\mathrm{KD}$ ini ialah siswa mampu memahami, menerapkan, menganalisis pengetahuan faktual, konseptual, prosedural, berdasarkan rasa ingin tahunya tentang ilmu pengetahuan terkait tentang teori model atom Dalton, Thomson, Rutherfod, Bohr, dan mekanika gelombang. Kemudian KD 4.2 telah memenuhi KI-4 keterampilan, dimana keterampilan yang akan diperoleh siswa berdasarkan KD ini ialah siswa mampu mengolah, menalar dan menyajikan dalam ranah konkrit dan ranah abstrak terkait dengan pengembangan dari yang dipelajarinya di sekolah secara mandiri, dan mampu menggunakan metode sesuai kaidah keilmuan terkait penggunaan model atom untuk menjelaskan fenomena alam atau hasil percobaan.

Kemudian dilakukan penyusunan tujuan pembelajaran dengan menyesuaikan dengan indikator pencapaian kompetensi yang telah dibuat. Pada RPP ini, tujuan pembelajarannya terdiri dari dua yaitu menjelaskan perkembangan teori atom untuk menunjukkan kelebihan dan kelemahan masing-masing teori atom, menentukan partikel dasar (proton, elektron, dan neutron) suatu atom berdasarkan nomor atom dan nomor massanya, dan mengklasifikasi unsur ke dalam isotop, isobar, dan isoton, mendefinisikan pengertian konfigurasi elektron dan bilangan kuantum, menuliskan konfigurasi elektron dan diagram orbital berdasarkan teori atom bohr, asas larangan pauli, prinsip aufbau dan kaidah hund, menentukan bilangan kuantum dari suatu atom, dan mempresentasikan hasil diskusi tentang perkembangan teori atom Dalton, Thomson, Rutherford, dan Bohr. Pada tujuan pertama terlihat bahwa tujuan ini sesuai dengan indikator pencapaian kompetensi 3.2.1, 3.2.2, 3.2.3, 3.2.4, 3.2.5 dan 3.2.6 sedangkan tujuan kedua sesuai dengan indikator pencapaian 4.2.1. Pada RPP guru, materi pembelajaran yang diajarkan telah sesuai dan mengacu pada tujuan pembelajaran.

\section{Menjelaskan Perkembangan Teori Atom untuk Menunjukkan Kelebihan dan Kekurangan masing-masing Teori Atom}

Pembahasan mengenai teori atom ini terbagi kedalam 4 konsep yang masing-masing mewakili tiap sub indikator. Distribusi tingkat penguasaan konsep siswa pada materi struktur atom sebagaimana pada tabel 8, menunjukkan bahwa sub indikator 1 dan sub indikator 2 penguasaan siswa berada pada kategori tinggi. Sedangkan untuk sub indikator 3 dan sub indikator 4 masih berada pada kategori rendah. Hal tersebut dapat terjadi karena teori atom Rutherford dan Bohr menjelaskan atom secara lebih mendalam sehingga membuat siswa rendah paham dalam teori atom tersebut. 


\section{Menentukan Partikel Dasar (Proton, Elektron, dan Neutron) Suatu atom berdasarkan Nomor Atom dan Nomor Massa}

Pembahasan mengenai partikel dasar penyusun atom ini terbagi kedalam 6 konsep yang masing-masing mewakili tiap sub indikator. Distribusi capaian konsep siswa tiap sub indikator pada semua indikator sebagaimana pada tabel 3, menunjukkan bahwa sub indikator 1 , sub indikator 2, sub indikator 3, dan sub indikator 4 penguasaan siswa berada pada kategori sedang. Sedangkan untuk sub indikator 5 dan sub indikator 6 masih berada pada kategori rendah. Hal tersebut dapat terjadi karena kurang teliti siswa dalam membaca soal serta ada beberapa siswa yang masih belum mengetahui tentang nomor atom dan nomor massa.

\section{Mengklasifikasi Unsur ke dalam Isotop, Isobar, dan Isoton}

Pembahasan mengenai isotop, isobar, dan isoton ini terbagi kedalam 3 konsep yang masing-masing mewakili tiap sub indikator. Distribusi capaian penguasaan konsep siswa tiap sub indikator sebagaimana pada tabel 8 , menunjukkan bahwa sub indikator 1 , sub indikator 2, dan sub indikator 3 penguasaan siswa berada pada kategori tinggi tetapi masih ada beberapa siswa yang salah konsep meskipun dapat menjawab dengan benar.

\section{Menentukan Bilangan Kuantum pada Elektron Terluar dari Suatu Unsur atau Ion}

Pembahasan mengenai bilangan kuantum ini terbagi kedalam 3 konsep yang masing-masing mewakili tiap sub indikator. Distribusi capaian konsep siswa tiap sub indikator pada semua indikator sebagaimana pada tabel 8 , menunjukkan bahwa sub indikator 1 penguasaan siswa berada pada kategori Sedang, pada sub indikator 2 penguasaan siswa berada pada kategori rendah, dan pada sub indikator 3 penguasaan siswa berada pada kategori rendah. Perolehan skor siswa memperlihatkan bahwa siswa lebih banyak memahami dalam menentukan bilangan kuantum unsur netral, sebagian siswa dapat menentukan bilangan kuantum ion negatif, dan semua siswa tidak dapat menentukan bilangan kuantum ion positif. Hal tersebut terjadi karena nomor atom unsur $\mathrm{Zn}^{2+}$ (ion positif) lebih besar sehingga kebanyakan siswa salah dalam membuat konfigurasi elektron. Karena soal ini merupakan pengetahuan berjenjang dimana setiap jawaban siswa saling berkaitan antara konfigurasi elektron, elektron valensi, diagram orbital, dan bilangan kuantum jika siswa sudah salah dalam menjawab konfigurasi elektron maka siswa juga akan salah dalam menjawab elektron valensi, diagram orbital dan juga bilangan kuantum sehingga sangat mempengaruhi hasil penguasaan konsep siswa.

\section{SIMPULAN}

Berdasarkan hasil penelitian dan analisis data yang telah dilakukan dapat disimpulkan bahwa profil penguasaan konsep struktur atom pada siswa kelas $\mathrm{X}$ MIPA-1 SMA Negeri 4 Palangka Raya 1) Rata-rata penguasaan konsep struktur atom siswa yaitu sebesar $62,16 \%$ berada pada kategori sedang. Penguasaan konsep siswa terbagi menjadi tiga kategori yaitu tinggi, sedang, dan rendah. Sebanyak 10 siswa berada pada kategori tinggi, sebanyak 13 siswa berada pada kategori sedang, dan sebanyak 7 siswa berada pada kategori rendah. 2) Siswa 
dapat menjelaskan perkembangan teori atom untuk menunjukkan kelebihan dan kekurangan masing-masing teori atom dengan penguasaan konsep sebesar 68,75\% berada pada kategori sedang. 3) Siswa dapat menentukan partikel dasar (proton, elektron, dan neutron) suatu atom berdasarkan nomor atom dan nomor massa dengan penguasaan konsep sebesar $61,47 \%$ berada pada kategori sedang. 4) Siswa dapat mengklasifikasi unsur ke dalam isotop, isobar, dan isoton dengan penguasaan konsep sebesar $88,88 \%$ berada pada kategori tinggi. 5) Siswa dapat menentukan bilangan kuantum pada elektron terluar dari suatu unsur atau ion dengan penguasaan konsep sebesar 21,04\% berada pada kategori rendah.

\section{DAFTAR PUSTAKA}

Anggraeni, M.E. 2018. Kemampuan Bernalar Ilmiah Mahasiswa Pada Mata Kuliah Kimia Teknik. Jurnal Ilmiah Kanderang Tingang. 9, 2 (Des. 2018), 150-165.

Arifin, M. 2007. Pengembangan Kurikulum dan Pembelajaran. Kimia. Jakarta: Universitas Terbuka.

Arifin, Z. 2011. Konsep dan Model Pengembangan Kurikulum. Bandung: PT: Remaja Rosdakarya.

Arikunto, S. 2007. Prosedur Penilaian Suatu Pendekatan Praktek Edisi Revisi VI. Jakarta : Rineka Cipta.

Asi, N.B. 2018. Dimensi Pengetahuan Dan Tingkat Berpikir Pada Pembelajaran Kimia. Jurnal Ilmiah Kanderang Tingang. 9, 2 (Des. 2018), 103-113.

Moleong, L. J. 2004. Metodologi Penelitian Kualitatif. Bandung: PT. Remaja Rosdakarya. 